\title{
PENGARUH MODEL PROBLEM BASED LEARNING BERBANTUAN MEDIA ANIMASI TERHADAP KOMPETENSI PENGETAHUAN IPA SISWA KELAS V
}

\author{
I K. I. Purnawan ${ }^{1}$, I B.G. S. Abadi ${ }^{2}$, D. B. K. N. S. Putra ${ }^{3}$ \\ ${ }^{123}$ Jurusan Pendidikan Guru Sekolah Dasar \\ Universitas Pendidikan Ganesha \\ Singaraja, Indonesia \\ e-mail : indrapurnawan711@yahoo.com ${ }^{1}$, suryaabadi31@yahoo.co.id ${ }^{2}$, \\ ngurahsemara@yahoo.com ${ }^{3}$.
}

\begin{abstract}
Abstrak
Penelitian ini bertujuan untuk mengetahui perbedaan yang signifikan kompetensi pengetahuan IPA siswa yang dibelajarkan menggunakan model Problem Based Learning berbantuan media Animasi dengan siswa yang dibelajarkan menggunakan pembelajaran konvensional. Jenis penelitian ini adalah quasi eksperimen dengan desain Nonequivalent control group design. Populasi dalam penelitian ini adalah seluruh siswa kelas V di SD Gugus I Gusti Ngurah Rai Denpasar Timur tahun pelajaran 2016/2017 yang berjumlah 293 orang. Penentuan sampel dalam penelitian ini dilakukan dengan teknik Purposive Sampling dengan terlebih dahulu mengundi kelas yang memenuhi syarat kemudian hasil undian diberikan pretest untuk menentukan kesetaraan. Setelah setara berdasarkan uji t dilakukan pengundian kembali untuk menentukan kelas eksperimen dan kontrol. Pengumpulan data dalam penelitian ini dilakukan dengan metode tes untuk mengumpulkan data kompetensi pengetahuan IPA siswa. Data nilai posttest kompetensi pengetahuan IPA dianalisis menggunakan uji t. Berdasarkan hasil uji hipotesis dengan uji $t$, diperoleh nilai $t_{\text {hitung }} 2,75>t_{\text {tabel }} 2,00$ pada taraf signifikan $5 \%$ dengan dk 65 maka $\mathrm{H}_{0}$ ditolak dan $\mathrm{H}_{\mathrm{a}}$ diterima. Hal ini menunjukan terdapat perbedaan yang signifikan kompentesi pengetahuan IPA antara siswa yang dibelajarkan melalui model Problem Based Learning berbantuan media Animasi dengan siswa yang dibelajarkan dengan pembelajaran konvensional pada siswa kelas V SD Gugus I Gusti Ngurah Rai. Selain itu, berdasarkan analisis dengan statistik deskriptif diperoleh hasil nilai rata-rata kompetensi pengetahuan IP kelas eksperimen 74,27 > kelas kontrol 68,09. Dengan demikian, dapat disimpulkan penerapan model Problem Based Learning berbantuan media Animasi berpengaruh terhadap kompetensi pengetahuan IPA siswa kelas V SD Gugus I Gusti Ngurah Rai Denpasar Timur tahun pelajaran 2016/2017.
\end{abstract}

Kata kunci: Problem Based Learning, media Animasi, kompetensi pengetahuan IPA

\begin{abstract}
This study aims to determine the significant differences in knowledge of science students using learning-assisted Problem Based Learning model of Animation media with students who are taught using conventional learning. This research type is quasi experiment with Nonequivalent control group design. Population in this research is all student of class $V$ at SD Gugus I Gusti Ngurah Rai East Denpasar year lesson 2016/2017 which amounts to 293 person.Pen sampel sample in this research done by technique of Purposive Sampling, first drawing class that eligible then drawing result given pretest to determine equality. After the equivalent on the basis of the t test the drawback is made to determine the experimental and control class. Data collection in this research is done by test method to collect data of science knowledge competence of
\end{abstract}


student. Data value posttest knowledge of IPA is analyzed using $t$ test. Based on the result of hypothesis test with $t$ test, obtained value tcount2,75> ttabel2,00 at 5\% significant level with dk 65 there $\mathrm{HO}$ rejected and Ha accepted. This shows that there was a significant difference of science knowledge competence between students who were taught through the model of Learning-based Intercourse with animation with students who were taught by conventional learning in grade V SD Gugus I Gusti Ngurah Rai. In addition, based on the analysis with descriptive statistics obtained the average value of knowledge competence of science class of experiments 74.27> control class 68.09. Thus, it could be concluded that the application of Problem Based Learning model assisted by the media of Animation has an effect on the knowledge competence of science students of grade V SD Gugus I Gusti Ngurah Rai East Denpasar academic year 2016/2017.

Keywords : Problem Based Learning, Animation media, science knowledge competence

\section{PENDAHULUAN}

Pasal 31 menyatakan pemerintah wajib memajukan pendidikan dengan mengusahakan dan menyelenggarakan satu sistem pendidikan nasional, untuk meningkatkan keimanan dan ketakwaan serta akhlak mulia dalam rangka mencerdaskan kehidupan bangsa, yang diatur dengan undang-undang, memprioritaskan anggaran pendidikan serta memajukan ilmu pengetahuan dan teknologi dengan menjunjung tinggi nilainilai agama dan persatuan bangsa untuk kemajuan peradaban serta kesejahteraan umat manusia. Upaya memenuhi janji kemerdekaan dan kesungguhan melaksanakan amanat konstitusi terkait dengan pendidikan semakin didukung oleh perundang-undangan. Visi Pendidikan Nasional pun menjadi semakin jelas. Penjelasan Undang-Undang Nomor 20 Tahun 2003 tentang Sistem Pendidikan Nasional menyatakan bahwa terwujudnya sistem pendidikan sebagai pranata sosial yang kuat dan berwibawa memberdayakan semua warga negara Indonesia berkembang menjadi manusia yang berkualitas sehingga mampu dan proaktif menjawab tantangan zaman yang selalu berubah. (Kemendikbud,2015:2)

Pendidikan adalah upaya yang terorganisasi, berencana dan berlangsung secara terus-menerus sepanjang hayat untuk membina anak didik menjadi manusia paripurna, dewasa, dan berbudaya. Untuk mencapai pembinaan ini asas pendidikan harus berorientasi pada pengembanagan seluruh aspek potensi anak didik, di antaranya aspek kognitif, afektif, dan berimplikasi pada aspek Psikomotorik. (Susanto,2015:85). Undangundang Sistem Pendidikan Nasional No. 20 Tahun 2003 tentang Sistem Pendidikan Nasional bahwa kurikulum merupakan seperangkat rencana dan pengaturan tentang tujuan, isi dan bahan pelajaran serta cara yang digunakan sebagai pedoman penyelenggara kegiatan pembelajaran untuk mencapai tujuan tertentu Menurut Permendikbud No 69 tahun 2013 lampiran I. Berdasarkan hal tersebut jelas bahwa kurikulum merupakan inti dari proses pendidikan. Kurikulum memuat rumusan tujuan yang harus dicapai, pengalaman belajar yang harus dimiliki oleh setiap siswa, dan strategi serta cara yang dapat dikembangkan. Mengingat pentingnya kurikulum tersebut maka pengembangan dan implementasinya agar efektif dan mampu mewujudkan keberhasilan serta meningkatkan mutu pendidikan.

Kurikulum yang mulai dikembangkan dan dilaksanakan secara bertahap saat ini di sekolah-sekolah adalah kurikulum 2013. Kurikulum 2013 bertujuan untuk mempersiapkan manusia Indonesia agar memiliki kemampuan hidup sebagai pribadi dan warga negara yang beriman, produktif, kreatif, inovatif, dan 
afektif serta mampu berkontribusi pada kehidupan bermasyarakat, berbangsa, bernegara, dan peradaban dunia menurut Permendikbud no 57 tahun 2014 lampiran I. Namun kenyataannya penerapan kurikulum 2013 dilapangan masih membuat siswa secara pasif menyerap struktur yang diberikan oleh guru yang terdapat di buku pelajaran. Dalam kurikulum 2013 siswa dituntut melalui beberapa proses secara aktif mencari, mengolah, mengkonstruksi, dan menerapkan pengetahuan. Maka sangat diperlukan upaya inovasi guru dalam mensiasati pembelajaran di kelas.

Kenyataan yang terjadi di lapangan saat ini berdasarkan hasil pengamatan pada proses pembelajaran di kelas $\mathrm{V}$ pada Gugus I Gusti Ngurah Rai, Kecamatan Denpasar Timur, penguasaan kompetensi pengetahuan IPA masih dibawah sandar. Hal ini di buktikan melalui nilai hasil ulangan akhir semester I yang masih banyak dibawah kkm. Hal ini dikarenakan pembelajaran yang masih bersifat teachercentered dimana proses pembelajaran lebih terpusat pada guru. Artinya, guru lebih mendominasi pembelajaran dan siswa berperan sebagai penerima informasi yang pasif.Hal itu membuat pembelajaran lebih menekankan pada siswa untuk mengingat, menghafal, dan mengerjakan tugas di buku pegangan sehingga tidak menekankan pada siswa untuk pemecahan masalah dan mengaplikasikan pengetahuannya.

Guru profesional yaitu guru yang tahu mendalam tentang apa yang diajarkanya, mampu mengajarkannya secara efektif, efisien, dan berkepribadian mantap (Alman,2010:127). Dalam hal ini kemampuan guru dalam medisain suatu pembelajaran sangat dibutuhkan. Disain pembelajaran yang menarik dapat diimplementasikan lewat model pembelajaran yang digunakan serta media yang dipilih.Pelaksanaan pembelajaran di kelas perlu didesain secara kreatif dan inovatif dengan memperhatikan karakteristik perkembangan siswa kelas V SD. Dari permasalahan tersebut dipandang perlu adanya inovasi dalam pembelajaran yakni pembelajaran yang mengutamakan penguasaan kompetensi, berpusat pada siswa, memberikan pengalaman belajar, dan relevan dengan kehidupan nyata. Salah satu inovasi yang dimaksud yakni dengan menerapkan model Problem Based Learning berbantuan Media Animasi.

Menurut Fathurrohman (2015:112)

Problem Based Learning adalah model pembelajaran yang melibatkan peserta didk untuk memecahkan masalah melalui tahapan-tahapan metode ilmiah sehingga peserta didk dapat mempelajari pengetahuan yang berhubungan dengan masalah tersebut dan sekaligus memiliki keterampilan untuk memecahkan masalah..Problem Based Learning (PROBLEM BASED LEARNING) dapat membuat siswa belajar melalui upaya pemyelesaian masalah dunia nyata (real world problem) secara terstruktur untuk mengkontruksi pengetahuan siswa. Pembelajaran berbasis masalah (Problem Based Learning ) didasarkan atas teori psikologi kognitif terutama berlandaskan teori Piaget dan Vigotsky (Kontruktivisme). Menurut teori Kontruktivisme, siswa belajar mengkontruksi pengetahuannya melalui interaksi dengan lingkungannya(Sani,2014:127). Sigit (2015:72) menyatakan "Problem Based Learning merupakan pendekatan dimana dalam proses pembelajaran dengan berdasarkan pada kurikulumnya, siswa dihadapkan kepada permasalahan sebagai langkah untuk memberikan rangsangan agar terjadi kegiatan belajar".

Selain model pembelajaran, untuk membuat pembelajaran semakin optimal dan lebih bermakna diperlukan media pembelajaran sebagai pendukung. "Media pembelajaran merupakan segala sesuatu yang dapat digunakan untuk menyalurkan pesan (bahan pembelajaran) sehingga dapat merangsang perhatian, minat, pikiran, dan perasaan peserta didik dalam kegiatan belajar untuk mencapai tujuan pembelajaran" Daryanto (2011:5). Salah satu media pembelajaran yang dapat 
membantu menyampaikan pesan pembelajaran dan meningkatkan minat belajar siswa media animasi. Media animasi adalah sebuah media pembelajaran yang dapat menampilkan gambar yang ditayangkan secara menarik sehingga dapat merangsang perhatian, minat, pikiran, dan perhatian siswa akan tertuju pada media yang ditampilkan sehingga tercapai tujuan pembelajaran. Karena melalui media pembelajaran tersebut siswa dapat melihat materi pembelajaran yang sedang diamati, dengan menggunakan indera pengelihatan pada pembelajaran maka pemahaman siswa lebih optimal dan lebih konkret.

Selama ini IPA hanya dibelajarkan dengan berpatokan pada buku pegangan sehingga kurang menarik bagi siswa. Model Problem Based Learning akan membuat pembelajaran IPA menjadi lebih menarik dan bermakna karena siswa diberikan kesempatan untuk membangun pengetahuannya sendiri melalui berbagai kegiatan sehingga pengetahuan yang didapat oleh siswa tidak bersifat hapalan semata. Model pembelajaran Problem Based Learning berbantuan media animasi akan membuat siswa lebih aktif, pembelajaran lebih menarik dan bermakna, karena selain model yang digunakan dapat meningkatkan keaktifan siswa dalam berpikir kritis dalam pemecahan masalah juga didukung dengan media yang menarik, membuat siswa terfokus, dan mampu menyampaikan pesan pembelajaran.

Berdasarkan hal tersebut dalam proses pembelajaran guru harus berperan aktif dalam memilih model dan media pembelajaran yang tepat bagi siswa. Melalui model Problem Based Learning berbantuan media animasi akan memperkuat tanggapan dan pengetahuan yang dimiliki siswa lebih konkret. Oleh sebab itu penelitian ini dilakukan untuk mengetahui apakah melalui model pembelajaran Problem based Learning berbantuan media animasi dapat berpengaruh secara signifikan pada kompetensi inti pengetahuan IPA, penelitian tersebut akan dilakukan dengan judul "Pengaruh Model PembelajaranProblem Based Learning BerbantuanMedia Animasi Terhadap Kompetensi Pengetahuan IPA Siswa Kelas VSD Gugus I Gusti Ngurah Rai Denpasar TimurTahun Pelajaran 2016/2017”.

Berdasarkan rumusan masalah tersebut, tujuan yang ingin dicapai dalam penelitian ini adalah sebagai berikut: 1) Untuk mengetahui kompetensi pengetahuan IPA kelompok siswa yang dibelajarkan dengan model pembelajaran problem based learning berbantuan media animasi pada siswa kelas V SD di Gugus I Gusti Ngurah Rai Denpasar Timur Tahun Pelajaran 2016/2017. 2) Untuk mengetahui kompetensi pengetahuan IPA kelompok siswa yang dibelajarkan secara konvensional pada siswa kelas V SD di Gugus I Gusti Ngurah Rai Denpasar Timur Tahun Pelajaran 2016/2017. 3) Untuk mengetahui perbedaan yang signifikan penguasaan kompetensi pengetahuan IPA antara kelompok siswa yang dibelajarkan dengan model pembelajaran problem based learning berbantuan media animasi dengan kelompok siswa yang dibelajarkan melalui pembelajaran konvensional pada siswa kelas V SD di Gugus I Gusti Ngurah Rai Denpasar Timur Tahun Pelajaran 2016/2017

\section{METODE PENELITIAN}

Penelitian ini akan dilaksanakan pada semester II di kelas V SD Negeri Gugus I Gusti Ngurah Rai Kecamatan Denpasar Timur Tahun Pelajaran $2016 / 2017$. Penelitian ini menggunakan jenis desain eksperimen semu (quasi experimental design) dengan menggunakan rancangan Nonequivalent Control Group Design. Dalam penelitian ini ada dua kelompok subjek yakni satu kelompok yang mendapatkan perlakuan khusus (eksperimen) dan satu kelompok yang tidak mendapatkan perlakuan khusus (kontrol). Kedua kelompok sama-sama memperoleh pretest dan posttest. Pelaksanaan penelitian ini terdiri dari tiga 
tahapan yaitu, tahap persiapan, tahap pelaksanaan, dan tahap akhir eksperimen.

Populasi pada penelitian ini adalah seluruh siswa kelas V SD Negeri di Gugus I Gusti Ngurah Rai Kecamatan Denpasar Timur Tahun Pelajaran 2016/2017, yang terdiri dari 9 kelas V dalam 7 SD. Jumlah populasi dari penelitian ini adalah 293 siswa dengan teknik pengambilan sampel pada penelitian ini adalah Purposive Sampling.

Kesetaraan sampel diuji dengan rumus uji-t yakni dengan polled varian dimana data nilai pretest harus memenuhi uji prasyarat yang meliputi uji normalitas dan homogenitas varians. Selanjutnya dilakukan pengundian lagi dari 2 sampel setara untuk memilih nama sekolah yang digunakan sebagai kelompok kontrol dan kelompok eksperimen. Hasil akhir pengundian ditetapkan siswa kelas V di SD Negeri 9 Kesiman sebagai kelas kontrol sedangkan siswa kelas V di SD Negeri 3 Penatih sebagai kelas eksperimen yang akan dilaksanakan kegiatan pengumpulan data pada kelas tersebut.

Kegiatan pengumpulan data dilaksanakan pada siswa kelas V SD Negeri Gugus I Gusti Ngurah Rai Kecamatan Denpasar Timur Tahun Ajaran 2016/2017 yang menjadi anggota sampel. Data yang diperlukan dalam penelitian ini dikumpulkan dengan metode tes. Tes yang akan digunakan untuk mengukur kompetensi pengetahuan IPA siswa berupa tes objektif dalam bentuk pilihan ganda biasa dilakukan pengujian instrumen yaitu uji validitas, daya beda, indeks kesukaran dan reliabilitas.

Suatu data dapat dikatakan baik apaila data tersebut bersifat falid, instrument penelitian harus memenuhi syarat validitas. "Agar dapat diperoleh data yang valid, instrumen atau alat ukur mengevaluasinya harus valid" (Suharsimi, 2015:79). Untuk mengukur validitas butir tes kompetensi pengetahuan IPA dalam bentuk objektif pilihan ganda digunakan rumus koofesien korelasi biserial $\left(\mathrm{\gamma}_{\mathrm{pbi}}\right)$.

Daya pembeda soal adalah kemampuan suatu soal untuk membedakan antara siswa yang pandai ( berkemampuan tinggi ) dengan siswa yang bodoh ( berkemampuan rendah ). Bagi suatu soal yang dapat dijawab benar oleh siswa pandai maupun siswa yang berkemampuan rendah, maka soal itu tidak baik karena tidak mempunyai daya pembeda. Demikian pula jika semua siswa baik pandai maupun yang berkemampuan rendah tidak dapat menjawab dengan benar, maka soal tersebut tidak baik juga karena tidak mempunyai daya pembeda.Angka yang menunjukkan besarnya daya pembeda disebut indeks diskriminasi, disingkat D (d besar). Indeks diskriminasi ini berkisar antara 0,00 sampai 1,00 .

Suatu instrument penelitian dikatakan mempunyai nilai reliabilitas yang tinggi, apabila tes yang dibuat mempunyai hasil yang konsisten dalam mengukur yang hendak diukur. Semakin reliabel suatu tes maka semakin yakin hasil suatu tes tersebut mempunyai hasil yang sama ketika dilakukan tes kembali (Sukardi, 2011:127). Uji reliabilitas dilakukan terhadap butir soal yang valid saja, dengan demikian uji reliabilitas bisa dilakukan setelah dilakukan uji validitas. Uji reliabilitas tes yang bersifat dikotomi dan heterogen ditentukan dengan rumus Kuder Richadson (KR-20).

Jika daya beda butir tes telah dihutung, selanjutnya dilakukan pengujian tingkat kesukaran. Angka yang menunjukkan sukar atau mudahnya suatu soal disebut indeks kesukaran (difficulty index). Besarnya indeks kesukaran antara $\leq$ 30 sampai dengan $\geq 0,70$. Indeks kesukaran ini menunjukkan taraf kesukaran soal. Soal dengan indeks kesukaran kurang dari 0,30 menunjukkan bahwa soal itu terlalu sukar, sebaliknya indeks lebih dari 0,70 menunjukkan bahwa soalnya terlalu mudah.

Setelah data kompetensi pengetahuan IPA sampel terkumpul, data tersebut akan dianalisis meng-gunakan statistik deskriptif daan statistik inferensial. Statistik deskriptif merupakan cara yang digunakan untuk menganalisis 
data dengan mendeskripsikan data yang terkumpul sebagaimana adanya. "Statistik deskriptif adalah suatu cara pengolahan data yang dilakukan dengan jalan menerapkan rumus-rumus statistik deskriptif untuk menggambarkan suatu objek/ variabel tertentu, sehingga diperoleh kesimpulan umum" (Agung, 2012: 110). Statistik deskriptif yang digunakan untuk mendeskripsikan data kompetensi pengetahuan IPA sampel adalah modus, median, mean, standar deviasi dan varian.

Rata-rata (mean) diperoleh atau dihitung dengan cara menjumlahkan seluruh skor yang diperoleh dan membaginya dengan jumlah subjek (jumlah skor). Tingkatan kompetensi pengetahuan IPA dapat dianalisis dengan membandingkan mean persen $(\mathrm{M} \%)$ ke dalam Penilaian Acuan Patokan (PAP) skala lima.

Untuk dapat memperoleh data skor yang memiliki frekuensi tertinggi digunakan perhitungan Modus. "Modus (Mo) adalah skor yang memiliki frekuensi tertinggi diantara skor-skor yang ada, dengan kata lain skor yang paling sering muncul diantara skor-skor yang ada" (Agung, 2016:43). Dengan demikian dapat dikatakan bahwa modus dapat ditentukan dengan cara melihat frekuensi tertinggi.

Selanjutnya, untuk menentukan nilai tengah dari data skor yang diperoleh, menggunakan perhintungan Median. "Median adalah skor-skor yang berada di tengah, yaitu 50 persen skor berada di atas dan 50 persen skor berada di bawah" (Setyosari, 2015:251). Dengan kata lain, median adalah nilai suatu angka yang membagi suatu distribusi data ke dalam dua bagian yang sama besar.

Selain modus, median dan mean, terdapat perhitungan standar deviasi dan varian data. Standar deviasi (s) adalah suatu ukuran persebaran atau dispersi skorskor. Sedangakn vaarians $\left(\mathrm{s}^{2}\right)$ adalah suatu angka yang menunjukkan ukuran variabilitas yang dihitung dengan jalan mengkuadratkan standar deviasi.

Setelah semua data dideskripsikan dengan statistik deskriptif, maka selanjutnya data kompetensi pengetahuan IPA siswa dalam bentuk statistik inferensial. Sebelum melakukan uji hipotesis maka harus dilakukan beberapa uji prasyarat di antaranya normalitas dan homogenitas.

Uji Normalitas sebaran data dalam penelitian ini menggunakan Chi-kuadrat. Kriteria pengujian adalah jika $X^{2}{ }_{\text {hitung }} \leq$ $X_{\text {tabel }}^{2}$ maka $\mathrm{H}_{\mathrm{o}}$ diterima (gagal ditolak) dan $\mathrm{H}_{\mathrm{a}}$ ditolak yang berarti sebaran data berdistribusi normal, sedangkan jika $X_{\text {hitung }}^{2}>X_{\text {tabel }}^{2}$ maka $\mathrm{H}_{\mathrm{o}}$ ditolak dan $\mathrm{H}_{\mathrm{a}}$ diterima (gagal ditolak) yang berarti data tidak berdistribusi normal.Taraf signifikansinya adalah $5 \%$ dan derajat kebebasannya $(\mathrm{dk})=\mathrm{k}-1$.

Setelah melakukan ujinormalitas data, dilakukan pengujian homogenitas varian data. Uji homogenitas varians dilakukan dengan uji F. Kriteria pengujian, jika $F_{\text {hit }}<F_{\text {tabel }}$ maka sampel homogen. Pengujian dilakukan pada taraf signifikansi 5\% dengan derajat kebebasan untuk pembilang $n_{1}-1$ dan derajat kebebasan untuk penyebut $\mathrm{n}_{2}-1$.

Jika data yang diperoleh sudah memenuhi prasyarat uji normalitas dan homogenitas maka analisis yang digunakan adalah statistik parametris. Analisis statistik yang digunakan untuk menguji hipotesis penelitian ini adalah uji beda mean (uji t). Uji Hipotesis menggunakan uji-t dengan rumus polled varian. Kriteria jika harga $t_{\text {hitung }} \leq t_{\text {tabel }}$, maka $\mathrm{H}_{\mathrm{o}}$ diterima dan $\mathrm{H}_{\mathrm{a}}$ ditolak, dan jika harga $\mathrm{t}_{\text {hitung }}>\mathrm{t}_{\text {tabel }}$ maka $\mathrm{H}_{\mathrm{o}}$ ditolak dan $\mathrm{H}_{\mathrm{a}}$ diterima. Pada taraf signifikansi $5 \%$ dengan $\mathrm{dk}=\mathrm{n}_{1}+\mathrm{n}_{2}-2$.

\section{HASIL DAN PEMBAHASAN}

Deskripsi data hasil penelitian ini memaparkan mengenai data kompetensi pengetahuan IPA siswa kelas V SD Negeri 3 Penatih sebagai kelompok eksperimen yang dibelajarkan dengan model pembelajaran Problem Based Learning berbantuan media animasi dan siswa kelas V SD Negeri 9 Kesiman sebagai kelompok kontrol yang dibelajarkan dengan pembelajaran konvensional. 


$\begin{array}{cccl}\text { Rekapitulasi } & \text { hasil } & \text { perhitungan } & \text { pengetahuan IPA sampel penelitian } \\ \text { statistik deskriptif } & \text { data } & \text { kompetensi } & \text { disajikan dalam tabel } 1 \text { berikut ini. }\end{array}$

Tabel 1. Hasil Analisis Data Penguasaan Kompetensi Pengetahuan IPA Sampel Penelitan

\begin{tabular}{lcc}
\hline & Kelompok Eksperimen & Kelompok Kontrol \\
\hline Nilai Minimum & 50 & 40 \\
\hline Nilai Maksimum & 87 & 83 \\
\hline Rata-rata & 74,27 & 68,09 \\
\hline Median & 76,08 & 67,98 \\
\hline Modus & 78,6 & 72,54 \\
\hline Standar Deviasi & 9,50 & 11,57 \\
\hline Varian & 90,20 & 133,95 \\
\hline
\end{tabular}

Berdasarkan hasil analisis data kompetensi pengetahuan IPA menunjukkan bahwa rerata kompetensi pengetahuan IPA siswa kelompok eskperimen $\bar{X}=74,27>\bar{X}=68$ kelompok kontrol. Apabila dikonversikan kedalam PAP skala lima maka, nilai rerata kompetensi pengetahuan IPA kelompok eksperimen sebesar 74,27\% dengan predikat sedang, sedangkan rerata kompetensi pengetahuan IPA kelompok kontrol sebesar $68,09 \%$ dengan predikat sedang.

Setelah dilakukan perhitungan statistik deskriptif, selanjutnya dilakukan perhitungan statistik inferensial. Statistik inferensial yang digunakan dalam penelitian ini adalah uji normalitas data dan homogenitas data. Pengetahuan IPA kelompok eksperimen dinyatakan berdistribusi normal. Sedangkan hasil uji normalitas data kelompok kontrol diperoleh $x^{2}$ hitung $=5,368$. Hasil hitung tersebut kemudian dibandingkan dengan $x^{2}$ tabel $=11,070$. Karena harga $x^{2}$ hitung $<$ harga $x^{2}$ tabelmaka data kompetensi pengetahuan IPA kelompok kontrol dinyatakan berdistribusi normal.

Berdasarkan hasil uji homogenitas varian data kompetensi pengetahuan IPA tersebut diperoleh $\mathrm{F}_{\text {hitung }}=1,46$. Hasil hitung tersebut dibandingkan dengan $\mathrm{F}_{\text {tabel }}=1,82$. Karena harga $F_{\text {hitung }}<$ harga $F_{\text {tabel }}$, maka varian data kompetensi pengetahuan IPA kelompok eksperimen dan kelompok kontrol dinyatakan homogeny

Tabel 2. Hasil Analisis Uji-t Data Kompetensi Pengetahuan IPA Sampel Penelitian

\begin{tabular}{clcccccc}
\hline No & \multicolumn{1}{c}{ Sampel } & $\mathrm{N}$ & $\mathrm{Dk}$ & $\overline{\boldsymbol{X}}$ & $\mathrm{s}^{2}$ & $t_{\text {hitung }}$ & $t_{\text {tabel }}$ \\
\hline 1 & Kelompok Eksperimen & 33 & \multirow{2}{*}{65} & 0,49 & 0,032 & \multirow{2}{*}{2,75} & \multirow{2}{*}{2,000} \\
2 & Kelompok Kontrol & 34 & & 0,38 & 0,025 & & \\
\hline
\end{tabular}

Berdasarkan data pada tabel tersebut, diketahui bahwa data penguasaan kompetensi pengetahuan IPA kelompok eksperimen dan kelompok kontrol memperoleh $t_{\text {hitung }}=2,75$. Harga $t_{\text {hitung }}$ tersebut dibandingkan dengan $t_{\text {tabel }}=2,000$. Karena harga $t_{\text {hitung }}>$ harga $t_{\text {tabel }}$, maka $\mathrm{H}_{\mathrm{o}}$ ditolak. Hal tersebut menunjukkan bahwa terdapat perbedaan yang signifikan kompetensi pengetahuan IPA antara kelompok siswa yang dibelajarkan dengan model pembelajaran Problem Based Learning berbantuan media animasi dan kelompok siswa yang dibelajarkan dengan pembelajaran konvensional pada kelas V SD Negeri Gugus I Gusti Ngurah Rai Kecamatan Denpasar Timur Tahun Pelajaran 2016/2017. 
Berdasarkan hasil temuan tersebut, dapat dinyatakan kedua kelompok sampel penelitian yang memiliki kemampuan setara, setelah diberikan perlakuan berupa pembelajaran dengan menggunakan model Problem Based Learning berbantuan media Animasi dan mengikuti pembelajaran menggunakan model pembelajaran konvensional diperoleh kompetensi pengetahuan yang berbeda. Hal ini dapat dilihat juga dari nilai rata-rata siswa yang mengikuti pembelajaran menggunakan model Problem Based Learning berbantuan media Animasi lebih tinggi dibandingkan dengan rata-rata siswa yang mengikuti pembelajaran konvensional. Perbedaan kompetensi pengetahuan dengan perolehan nilai rata-rata yang lebih tinggi pada kelompok eksperimen dibandingkan kelompok kontrol disebabkan oleh perlakuan berupa model Problem Based Learning berbantuan media Animasi dalam kompetensi pengetahuan IPA diberikan pada kelompok eksperimen.

Pada kelompok eksperimen, kegiatan pembelajaran dalam muatan materi IPA menggunakan model Problem Based Learning berbantuan media Animasi berjalan dengan optimal dan kondusif. Hal ini disebabkan oleh model Problem Based Learning berbantuan media Animasi merupakan suatu inovasi pembelajaran yang menekankan penguasaan bahan - bahan pelajaran melalui pemecahan permasalahan yang dihadapi dalam materi pembelajaran yang dibantu dengan Animasi sebagai media pembelajaran yang mumpuni. Selama kegiatan pembelajaran siswa dapat membangun pengetahuannya dengan cara memecahkan masalah yang ada dengan asas keilmiahannya sehingga pengetahuan yang mereka peroleh tidak hanya bersifat hafalan melainkan sebuah pemahaman nyata. Selama kegiatan pembelajaran siswa lebih aktif karena kegiatan pembelajaran menggunakan model Problem Based Learning berbantuan media Animasi menciptakan lingkungan belajar yang menarik dengan animasi sebagai media pembelajaran dan memberikan kebebasan siswa untuk mengemukakan pendapat dan mengasah keterampilan pemecahan masalahnya.

Hasil temuan pada penelitian ini memiliki persamaan dengan penelitian sebelumnya yang relevan dan memperkuat hasil penelitian yang diperoleh, hal tersebut didukung oleh penelitian yang relevan, yakni penelitian yang dilakukan oleh Marga (2014) Model Problem based Lerning berbantuan media Visual Animasi terhadap hasil belajar IPA siswa kelas V di gugus II Tampaksiring Gianyar yang berpengaruh signifikan. Penelitian lain yang juga mendukung hasil penelitian ini, yakni dilakukan penelitian oleh Supriadi (2013) Model Problem based Lerning berbantuan media Audiovisual terhadap hasil belajar IPS siswa kelas IV di gugus Ubud Gianyar yang berpengaruh signifikan. Namun dalam penelitian ini dilakukan penelitian tentang pengaruh penerapan model Problem Based Learning berbantuan media animasi terhadap kompetensi IPA siswa. Dengan demikian, pembelajaran menggunakan model Problem Based Learning berbantuan media animasi pada penelitian ini memiliki keunggulan yakni dapat membuat siswa lebih aktif dalam pembelajaran dan meningkatkan kemampuan berpikir siswa dengan memberikan pengalaman yang berkesan bagi siswa didukung oleh peran guru dalam pemberian materi, tidak adanya diskriminasi, serta pengakuan atas usaha yang dilakukan.

\section{SIMPULAN DAN SARAN}

Berdasarkan hasil analisis data kompetensi pengetahuan IPA pada kelompok eksperimen yang dibelajarkan dengan model Problem Based Learning berbantuan media Animasi mendapat nilai yang cenderung tinggi. Dari perhitungan modus, median dan mean menunjukan nilai modus sebesar78,6 lebih besar dari median sebesar76,08 dan mean sebesar 74,27

Berdasarkan hasil analisis data kompetensi pengetahuan IPA pada kelompok kontrol yang dibelajarkan pembelajaran konvensional mendapat nilai yang cenderung rendah. Dari perhitungan 
modus, median dan mean menunjukan nilai modussebesar 72,54 lebih kecil dari median sebesar 72,54 dan mean sebesar 68,09

Berdasarkan hasil analisis dengan menggunakan uji-t diproleh $t_{\text {hitnung }}=2,75$ sedangkan pada taraf signifikansi $5 \%$ dan dk $=65$ diperoleh nilai $t_{\text {tabel }}=2,00$ sehingga $t_{\text {hitnung }}=2,75>t_{\text {tabel }}=2,00$. Dengan demikian, hipotesis nol (Ho) ditolak. Hal ini berarti terdapat perbedaan yang signifikan kompetensi pengetahuan IPA antara kelompok siswa yang dibelajarkan dengan model Problem Based Learning berbantuan media Animasi.

Berdasarkan hasil penelitian ini, maka saran yang dapat disampaikan adalah 1) Guru hendaknya dapat menambah wawasannya mengenai inovasi pembelajaran sehingga mampu menerapkan ataupun mengembangkan pembelajaran di kelas secara lebih inovatif dan bervariasi agar dapat memberikan dampak positif dalam meningkatkan kompetensi pengetahuan siswa. Salah satu model pembelajaran yang dapat direkomendasikan untuk guru dalam menciptakan pembelajaran yang bervariasi adalah model Problem Based Learning berbantuan media animasi. 2)Sekolah hendaknya dapat berkontribusi penuh dalam meningkatkan kualitas serta mengoptimalkan proses pembelajaran, sehingga berdampak positif pada kompetensi pengetahuan siswa khususnya di sekolah dasar. 3)Peneliti lain agar dapat mengembangkan berbagai model pembelajaran lain pada subyek penelitian yang berbeda sehingga proses pembelajaran dapat berlangsung optimal dan memberikan dampak positif bagi kompetensi pengetahuan siswa.

\section{DAFTAR RUJUKAN}

Agung, A. A. G. 2014. Metodelogi Penelitian Pendidikan. Malang : Aditya Media Publishing.

Agung, A. A. G. 2016. Statistika Dasar untuk Pendidikan. Yogyakarta: Deepublish
Dantes, Nyoman (Ed). 2010. Pembelajaran Agama Hindu Berwawasan Sains.Surabaya: Paramita.

Dantes, Nyoman 2012. Metodelogi Penelitian. Yogyakarta : CV Andi Offset

Darmadi, Hamid. 2014 Metode Penelitian Pendidikan dan Sosial. Bandung : Alfabeta

Daryanto, 2014 Pendekatan Pembelajaran Saintifik, Yogyakarta : Gava Media

Daryanto. 2011. Media Pembelajaran. Bandung : Sarana Tutorial Nurani Sejahtera

Emzir. 2015. Metodologi Penelitian Pendidikan. Jakarta: Rajawali Pers

Fathurrohman, Muhammad. 2015. Modelmodel Pembelajaran Inovatif. Jogjakarta: AR-Ruzz Media

Kementrian Pendidikan dan Kebudayaan. 2013. Peraturan Menteri Pendidikan dan Kebudayaan Republik Indonesia Nomor 69 Tahun 2013. Jakarta: Kemendikbud.

Kementrian Pendidikan dan Kebudayaan. 2014. Peraturan Menteri Pendidikan dan Kebudayaan Republik Indonesia Nomor 57 Tahun 2014. Jakarta: Kemendikbud.

Kementrian Pendidikan dan Kebudayaan. 2014. Peraturan Menteri Pendidikan dan Kebudayaan Republik Indonesia Nomor 103 Tahun 2014. Jakarta: Kemendikbud.

Kermendikbud.2015. Nomor 53 tentang Penilaian Hasil Belajar oleh Pendidik dan Satuan Pendidikan Dasar dan Pendidikan Menengah.. Jakarta: Permendikbud

Kohiri, Wafik. (2013). "Problem Based Learning Berbantuan Multimedia Dalam Pembelajaran Matematika 
Untuk Meningkatkan Kemampuan Berpikir Kreatif'. Skripsi (tidak diterbitkan) .UNNES

Kosasih, E. 2014. Strategi Belajar dan Pembelajaran Implementasi Kurikulum 2013. Bandung: Yrama Widya.

Kunandar. 2014. Penilaian Autentik. Jakarta: Rajawali Pers

Kurniasih, Imas dan Berlin Sani. 2016. Ragam Pengembangan Model Pembelajaran. Surabaya: Kata Pena

Mercury, M.Fredey. 2015. "Pengaruh Model PBL Berbantuan Multimedia Interaktif Terhadap Hasil Belajar IPS Kelas Vii SMP N 3 Sawan". Skripsi (tidak diterbitkan ). UNDIKSHA

Munir. 2012. Multimedia Konsep dan Alikasi dalam Pendidikan. Bandung: Alfabeta

Rusman. 2016. Model-model Pembelajaran. Jakarta: Raja Grafindo Persada

Sandy, I Putu Angga Wijaya . 2016. "Penerapan PBL Dalam Pendekatan Saintifik Untuk Meningkatkan Kemampuan Berpikir Kritis Dan Penguasaan Kompetensi Pengetahuan IPS siswa kelas IVA SD 2 dangin Puri tahun ajaran 2015/2016". Skripsi (Tidak diterbitkan).UNDIKSHA
Sani, Ridwan Abdulah. 2014. Pembelajaran Saintifik Untuk implementasi Kurikulum 2013. Jakarta: Bumi Aksara

Setyosari, Punaji. 2015. Metode Penelitian Pendidikan dan Pengembangan. Jakarta: Kencana

Sudijono, Anas. 2013. Pengantar Evaluasi Pendidikan. Jakarta: Rajawali Pers

Sugiyono. 2010. Metode Penelitian Kuantitatif, Kualitatif, dan $R \& D$. Cetakan ke-12. Bandung:Alpabeta.

Sugiyono. 2016. Statistikan untuk Penelitian. Jakarta: Alfabeta.

Suharsimi, Suharsimi. 2012. Dasar- dasar Evaluasi Pendidikan. Jakarta: Bumi Aksara

Supriadi, I Md. 2013. Model Pembelajaran Problem Based Learning (PBL) Berbantuan Media Audiovisual Berpengaruh Terhadap Hasil Belajar IPS Siswa Kelas IV SD Gugus Ubud Gianyar. Skripsi (tidak diterbitkan.). UNDIKSHA

Triwiyanto, Teguh. 2014. Pengantar Pendidikan. Jakarta: Bumi Aksara.

Utami,Dina.2011."Animasi dalam Pembelajaran".Majalah Pembelajaran, Volume 7, Nomor 1 hlm.44). 
